\title{
MOLECULAR STRUCTURE AND CHEMICAL PROPERTIES OF A BINUCLEAR CYCLOPENTADIENYLCOBALT NITROSYL CATION
}

\author{
FRANZ WOCHNER, EGBERT KELLER and HANS H. BRINTZINGER \\ Fakultät für Chemie, Universität Konstanz, Postfach 5560, 7750 Konstanz (B.R.D.)
}

\section{Summary}

The spectroscopic, structural and chemical properties of the binuclear cation $\left(\mathrm{C}_{5} \mathrm{H}_{5}\right)_{2} \mathrm{Co}_{2}(\mu-\mathrm{NO})_{2}{ }^{+}$are described.

\section{Introduction}

Cationic cyclopentadienylcobalt nitrosyl derivatives have been shown by Clamp et al. [1] to be formed in reactions of $\left(\mathrm{C}_{5} \mathrm{H}_{5}\right) \mathrm{Co}(\mathrm{CO})_{2}$ with $\mathrm{NOPF}_{6}$. Correspondingly, we find that reaction of $\left(\mathrm{C}_{5} \mathrm{H}_{5}\right) \mathrm{Co}(\mathrm{CO})_{2}$ with nitrosyl salts in $\mathrm{CH}_{2} \mathrm{Cl}_{2}$ solution affords the binuclear mono-cation $\left(\mathrm{C}_{5} \mathrm{H}_{5}\right)_{2} \mathrm{Co}_{2}(\mu-\mathrm{NO})_{2}^{+}$, the existence of which had previously been inferred by Bernal et al. [2] from electrochemical studies on the neutral binuclear nitrosyl compound $\left(\mathrm{C}_{5} \mathrm{H}_{5}\right)_{2} \mathrm{Co}_{2}$ $(\mu-\mathrm{NO})_{2}$ [3]. Since the IR spectral characteristics of this cation, a single NOabsorption at $1620 \mathrm{~cm}^{-1}$, are quite different, however, from those reported for this species in ref. 1 , we have established its identity by additional chemical evidence and by a determination of its crystal and molecular structure.

\section{Results}

The cation $\left(\mathrm{C}_{5} \mathrm{H}_{5}\right)_{2} \mathrm{Co}_{2}(\mu-\mathrm{NO})_{2}{ }^{+}(1)$ is formed in $40-50 \%$ yield either as its $\mathrm{PF}_{6}$ or as its $\mathrm{BF}_{4}$ salt when $\left(\mathrm{C}_{5} \mathrm{H}_{5}\right) \mathrm{Co}(\mathrm{CO})_{2}$ is treated with equimolar quantities or with a slight excess of $\mathrm{NOPF}_{6}$ or $\mathrm{NOBF}_{4}$ in $\mathrm{CH}_{2} \mathrm{Cl}_{2}$ at room temperature. The product crystallizes in form of dark red platelets from $\mathrm{CH}_{2} \mathrm{Cl}_{2}$ /pentane. Both the $\mathrm{BF}_{4}$ and $\mathrm{PF}_{6}$ salts of 1 are fairly soluble (ca. $10^{-2} \mathrm{M}$ ) in $\mathrm{CH}_{2} \mathrm{Cl}_{2}$, but much less so in $\mathrm{CHCl}_{3}, \mathrm{CCl}_{4}$ and in less polar organic solvents. The crystalline product is quite stable in the air, but in solution, exposure to air causes decomposition within less than one hour.

The IR spectrum of the cation 1 in $\mathrm{CH}_{2} \mathrm{Cl}_{2}$ solution is dominated by a very strong $\nu$ (NO) absorption at $1620 \mathrm{~cm}^{-1}$ (at $1610 \mathrm{~cm}^{-1}$ in Nujol mull). Weaker 
absorptions at $3093,1398,1017,992$ and $810-820 \mathrm{~cm}^{-1}$, assignable to the $\eta$ - $\mathrm{C}_{5} \mathrm{H}_{5}$-rings, are partly hidden by the strong absorptions of the $\mathrm{PF}_{6}{ }^{-}$or the $\mathrm{BF}_{4}{ }^{-}$anion at about 845 and $1060 \mathrm{~cm}^{-1}$, respectively.

Crystals suitable for X-ray structural work were obtained from $\mathrm{CH}_{2} \mathrm{Cl}_{2}$ /pentane solutions of $\left(\mathrm{C}_{5} \mathrm{H}_{5}\right)_{2} \mathrm{Co}_{2}(\mu-\mathrm{NO})_{2} \mathrm{BF}_{4}$. X-ray diffraction intensities were determined on a Syntex-P3 four-circle diffractometer at $293 \mathrm{~K}\left(\mathrm{Mo}-K_{\alpha}, \lambda=\right.$ $71.069 \mathrm{pm}$, graphite monochromator, $\omega$-scan with $2.0<\omega / t<29.3^{\circ} \mathrm{min}^{-1}$ ) and $2<2 \theta<42^{\circ}$. One standard reflection was measured for every 100 reflections during data collection as a check on crystal and instrumental stability.

The crystals are monoclinic, space group $C 2 / c ; a 1788(1), b 994.6(2), c$ $1947(1) \mathrm{pm}, \beta 123.73 ; V 2878 \cdot 10^{6} \mathrm{pm}^{3}, d_{\text {calc }} 1.82 \mathrm{~g} / \mathrm{cm}^{-3}$ for $M=394.9$ and $Z=8 ; d_{\exp } 1.76 \mathrm{~g} / \mathrm{cm}^{-3}$. The unit cell contains one $\mathrm{BF}_{4}{ }^{-}$and two crystallographically independent half-units of $\left(\mathrm{C}_{5} \mathrm{H}_{5}\right)_{2} \mathrm{Co}_{2}(\mu-\mathrm{NO})_{2}{ }^{+}$per asymmetric unit; the two halves of each $\left(\mathrm{C}_{5} \mathrm{H}_{5}\right)_{2} \mathrm{Co}_{2}(\mu-\mathrm{NO})_{2}{ }^{+}$unit are related to each other by a crystallographic center of symmetry.

The structure was solved by direct methods and refined (SHELXTL program [4]) using 915 reflections with $F_{0}>40$ with anisotropic temperature parameters for $\mathrm{Co}, \mathrm{N}, \mathrm{O}$ and $\mathrm{F}$ and isotropic temperature parameters for $\mathrm{C}$ and $\mathrm{B}$ atoms. Hydrogen atoms were not determined. The refinement resulted in values of $R_{1}=0.082$ and $R_{2}=0.084$. Residual electron density was $\leqslant 1.0 \mathrm{e} / 10^{6} \mathrm{pm}^{3}$ throughout.

The results (see Table 1) indicate some disorder of the $\mathrm{BF}_{4}{ }^{-}$units: The tem-

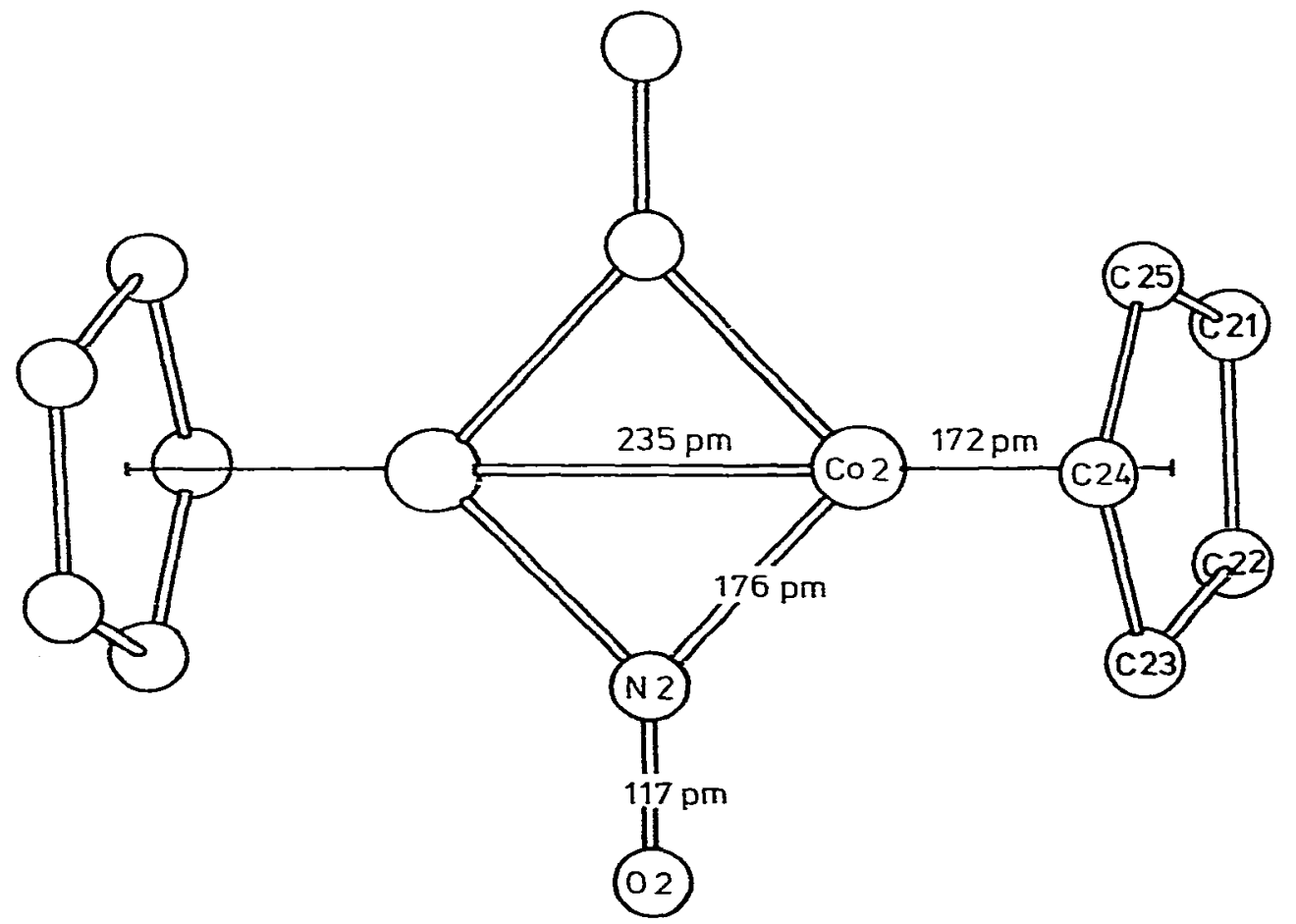

Fig. 1. Nolecular structure of $\left(\mathrm{C}_{5} \mathrm{H}_{5}\right)_{2} \mathrm{CO}_{2}(\mu-\mathrm{NO})_{2}{ }^{+}$. 
TABLE 1

STRUCTURAL PAR AMETERS FOR $\left(\mathrm{C}_{5} \mathrm{H}_{5}\right)_{2} \mathrm{CO}_{2}\left(\mu \cdot \mathrm{NO}_{2} \mathrm{BF}_{4}\right.$

FRACTIONAL COORDINATES (with e.s, $(i$,'s) AND THERMAL PARAMETERS

\begin{tabular}{|c|c|c|c|c|c|c|c|c|c|}
\hline Alom & $x / a$ & $y / b$ & $z / c$ & $v_{11}$ or $U$ & $u_{22}$ & $U_{3 \mathfrak{3}}$ & $U_{23}$ & $U_{13}$ & $v_{12}$ \\
\hline $\operatorname{Co}(1)$ & $0.4211(2)$ & $0.0700(3)$ & $0.2066(2)$ & $0.074(2)$ & $0.054(2)$ & $0.063(2)$ & $-0.002(2)$ & $0.040(2)$ & $0.003(2)$ \\
\hline$N(1)$ & $0.504(1)$ & $0.070(2)$ & $0.184(1)$ & $0.106(14)$ & $0.101(14)$ & $0.049(11)$ & $0.004(11)$ & $0.051(11)$ & $0.012(12)$ \\
\hline$O(1)$ & $0.510(1)$ & $0.070(2)$ & $0,127(1)$ & $0.131(14)$ & $0.152(10)$ & $0.076(11)$ & $-0.011(12)$ & $0,063(11)$ & $0.009(13)$ \\
\hline$c(11)$ & $0.301(2)$ & $0.018(3)$ & $0.193(2)$ & $0.103(8)$ & & & & & \\
\hline$C(12)$ & $0.307(2)$ & $-0.045(3)$ & $0.130(2)$ & $0.117(9)$ & & & & & \\
\hline$C(13)$ & $0.312(2)$ & $0.057(3)$ & $0.084(2)$ & $0.105(8)$ & & & & & \\
\hline$C(14)$ & $0.310(2)$ & $0.188(3)$ & $0.117(1)$ & $0.097(8)$ & & & & & \\
\hline$C(15)$ & $0.307(2)$ & $0.164(2)$ & $0,184(1)$ & $0,000(7)$ & & & & & \\
\hline $\operatorname{Co}(2)$ & $-0.0016(2)$ & $0.0981(8)$ & $0,0327(2)$ & $0.080(2)$ & $0.065(2)$ & $0,075(2)$ & $0.006(2)$ & $0,048(2)$ & $0.003(2)$ \\
\hline$N(2)$ & $0.038(2)$ & $0.067(2)$ & $-0.030(2)$ & $0.328(36)$ & $0,112(18)$ & $0.189(24)$ & $-0.021(18)$ & $0.216(27)$ & $-0.076(22)$ \\
\hline$O(2)$ & $0.070(3)$ & $0.127(2)$ & $-0,060(2)$ & $0.548(55)$ & $0.090(15)$ & $0.357(38)$ & $-0.030(19)$ & $0.405(44)$ & $-0.039(24)$ \\
\hline$C(21)$ & $-0.085(2)$ & $0.221(2)$ & $0.053(1)$ & $0.085(7)$ & & & & & \\
\hline$C(22)$ & $-0.052(2)$ & $0.295(3)$ & $0.012(1)$ & $0.100(8)$ & & & & & \\
\hline$c(23)$ & $0.055(2)$ & $0.293(2)$ & $0.072(1)$ & $0.086(7)$ & & & & & \\
\hline$C(24)$ & $0.070(2)$ & $0.219(3)$ & $0.140(1)$ & $0.097(8)$ & & & & & \\
\hline$C(25)$ & $-0.010(2)$ & $0.175(2)$ & $0,129(1)$ & $0,096(8)$ & & & & & \\
\hline B & $0.224(3)$ & $0.941(4)$ & $-0,150(2)$ & $0.100(10)$ & & & & & \\
\hline$F(1)$ & $0.289(1)$ & $-0,027(2)$ & $0.393(1)$ & $0.120(13)$ & $0,098(13)$ & $0.315(27)$ & $0.018(15)$ & $0.094(16)$ & $0.024(11)$ \\
\hline$F(2)$ & $0.252(1)$ & $0.162(2)$ & $0.326(1)$ & $0.186(17)$ & $0,133(14)$ & $0.134(13)$ & $0.005(11)$ & $0.086(13)$ & $-0.024(13)$ \\
\hline$F(3)$ & $0.217(2)$ & $0.106(3)$ & $0.407(2)$ & $0.327(33)$ & $0.317(33)$ & $0.329(33)$ & $0.059(29)$ & $0.287(32)$ & $0.052(29)$ \\
\hline$\Gamma(4)$ & $0.156(2)$ & $0.002(2)$ & $0.295(1)$ & $0.258(26)$ & $0.174(20)$ & $0.173(20)$ & $0.068(17)$ & $-0.045(19)$ & $-0.103(20)$ \\
\hline
\end{tabular}

INTERATOMIC DISTANCES (in pm) AND BDND ANGLES (in degrees)

\begin{tabular}{|c|c|c|c|c|c|c|c|}
\hline \multicolumn{2}{|l|}{ Molecule 1} & \multicolumn{2}{|l|}{ Molenule 2} & \multicolumn{2}{|l|}{ Molecule 1} & \multicolumn{2}{|l|}{ Molecule 2} \\
\hline \multicolumn{4}{|l|}{ Distancas } & \multicolumn{4}{|l|}{ Angles } \\
\hline $\mathrm{Co}(1)-\mathrm{Co}\left(1^{\prime}\right)$ & $234.77(6)$ & $\operatorname{Co}(2)-\operatorname{Co}\left(2^{\prime}\right)$ & $234.8(6)$ & $N(1)-C o(1)-N\left(1^{\prime}\right)$ & $97(1)$ & $N(2)-C o(2)-N\left(2^{\prime}\right)$ & $96(2)$ \\
\hline $\operatorname{Co}(1)-N(1)$ & $177(2)$ & $\mathrm{Co}(2)-\mathrm{N}(2)$ & $175(4)$ & $\operatorname{Co}(1)-N(1)-\operatorname{Co}\left(1^{1}\right)$ & $83(1)$ & $\operatorname{Co}(2)-N(2)-\operatorname{Co}\left(2^{\prime}\right)$ & $84(1)$ \\
\hline $\mathrm{Co}(1)-\mathrm{N}\left(1^{\prime}\right)$ & $177(2)$ & $\mathrm{Co}(2)-\mathrm{N}\left(2^{i}\right)$ & $176(3)$ & $\mathrm{Co}(1)-\mathrm{N}(1)-\mathrm{O}(1)$ & $140(1)$ & $\mathrm{Co}(2)-\mathrm{N}(2)-\mathrm{O}(2)$ & $139(2)$ \\
\hline$N(1)-0(1)$ & $118(3)$ & $N(2)-O(2)$ & $117(6)$ & $\operatorname{Co}(1)-N\left(1^{\prime}\right)-O\left(1^{\prime}\right)$ & $137(2)$ & $\mathrm{Co}(2)-\mathrm{N}\left(2^{t}\right)-\mathrm{O}\left(2^{t}\right)$ & $137(3)$ \\
\hline $\mathrm{Co}(1)-\mathrm{C}(\mathrm{av})$ & $208(3) \pm 3$ & $C o(2)-C(a v)$ & $211(3) \pm 1$ & & & & \\
\hline $\mathrm{C}-\mathrm{C}$ (av) & $142(5) \pm 7$ & $\mathrm{C}-\mathrm{C}(\mathrm{av})$ & $145(4) \pm 6$ & & & & \\
\hline \multicolumn{4}{|c|}{$B-F$ (av) $128(5) \pm 6$} & \multicolumn{4}{|c|}{$F-B-F(a v) 109(3) \pm 10$} \\
\hline
\end{tabular}


perature parameters of the $F$ atoms are large and a relatively high residual electron density $\left(0.8-1 e / 10^{6} \mathrm{pm}^{3}\right)$ is situated about $120-140 \mathrm{pm}$ from the $\mathrm{B}$ atom. In one of the two independent $\left(\mathrm{C}_{5} \mathrm{H}_{5}\right)_{2} \mathrm{Co}_{2}(\mu-\mathrm{NO})_{2}{ }^{+}$units, the temperature parameters of $\mathrm{N}$ and $\mathrm{O}$ are twice as large as those of the other unit; the orientations of the thermal elipsoids indicate a fairly high degree of librational freedom of both NO ligands around the $\mathrm{Co}-\mathrm{Co}$ axis.

In all other respects, the two independent $\left(\mathrm{C}_{5} \mathrm{H}_{5}\right)_{2} \mathrm{Co}_{2}(\mu-\mathrm{NO})_{2}{ }^{+}$units are identical within limits of standard deviations. The $\mathrm{Co}, \mathrm{N}$ and $\mathrm{O}$ atoms of the $\mathrm{Co}(\mu-$ $\mathrm{NO})_{2} \mathrm{Co}$ core are all coplanar within standard deviations. The $\mathrm{Co}-\mathrm{Co}, \mathrm{Co}-\mathrm{N}$ and $\mathrm{N}-\mathrm{O}$ bond distances (Table 1 ) are quite similar to, albeit marginally (2-6 $\mathrm{pm}$ ) shorter than those reported for the isoelectronic species $\left(\mathrm{C}_{5} \mathrm{R}_{5}\right)_{2} \mathrm{Co}_{2}(\mu-\mathrm{CO})$ ( $\mu$-NO) [2] and $\left(\mathrm{C}_{5} \mathrm{R}_{5}\right)_{2} \mathrm{Co}_{2}(\mu-\mathrm{CO})_{2}{ }^{-}\left(\mathrm{R}=\mathrm{H}, \mathrm{CH}_{3}\right)$ [5,6]. Comparison with the neutral binuclear nitrosyl $2,\left(\mathrm{C}_{5} \mathrm{H}_{5}\right)_{2} \mathrm{Co}_{2}(\mu-\mathrm{NO})_{2}$ [2] reveals that a very slight shortening of the Co-Co bond (235 vs. $237 \mathrm{pm}$ ) and a somewhat more pronounced shortening of the $\mathrm{Co}-\mathrm{N}$ bonds $(176 \pm 1 \mathrm{vs} .183 \mathrm{pm})$ is associated with the one-electron oxidation $2 \rightarrow 1$. As with the other binuclear $\left(\mathrm{C}_{5} \mathrm{H}_{5}\right)_{2} \mathrm{Co}_{2} \mathrm{com}$ pounds mentioned above, both $\mathrm{C}_{5} \mathrm{H}_{5}$ rings are parallel to each other and perpendicular to the $\mathrm{Co}-\mathrm{Co}$ axis.

The close structural relationship between 1 and its neutral analogue 2 suggests a facile mutual interconversion of these two compounds by oxidationreduction reactions. Previous cyclic voltametry studies $[1,2]$ have indicated reversible oxidation-reduction reactions in this series. We have observed some stoichiometric reactions of the binuclear cation 1 as follows. When a solution of 1 in $\mathrm{CH}_{2} \mathrm{Cl}_{2}$ is stirred with $\mathrm{Zn}$ powder at room temperature, its IR spectrum changes completely to that of the neutral binuclear compound $2(\nu(\mathrm{NO})$ at 1530 and $1590 \mathrm{~cm}^{-1}$ ) [3] during $4-5 \mathrm{~h}$. Oxidation of 2 to 1 is brought about when a $\mathrm{CH}_{2} \mathrm{Cl}_{2}$ solution of 2 is stirred with solid $\mathrm{AgBF}_{4}$. This reaction goes to completion, in about $5 \mathrm{~h}$, using one equivalent of $\mathrm{AgBF}_{4}$ per cyclopentadienylcobalt nitrosyl dimer, in accord with the mono-cationic charge of 1.

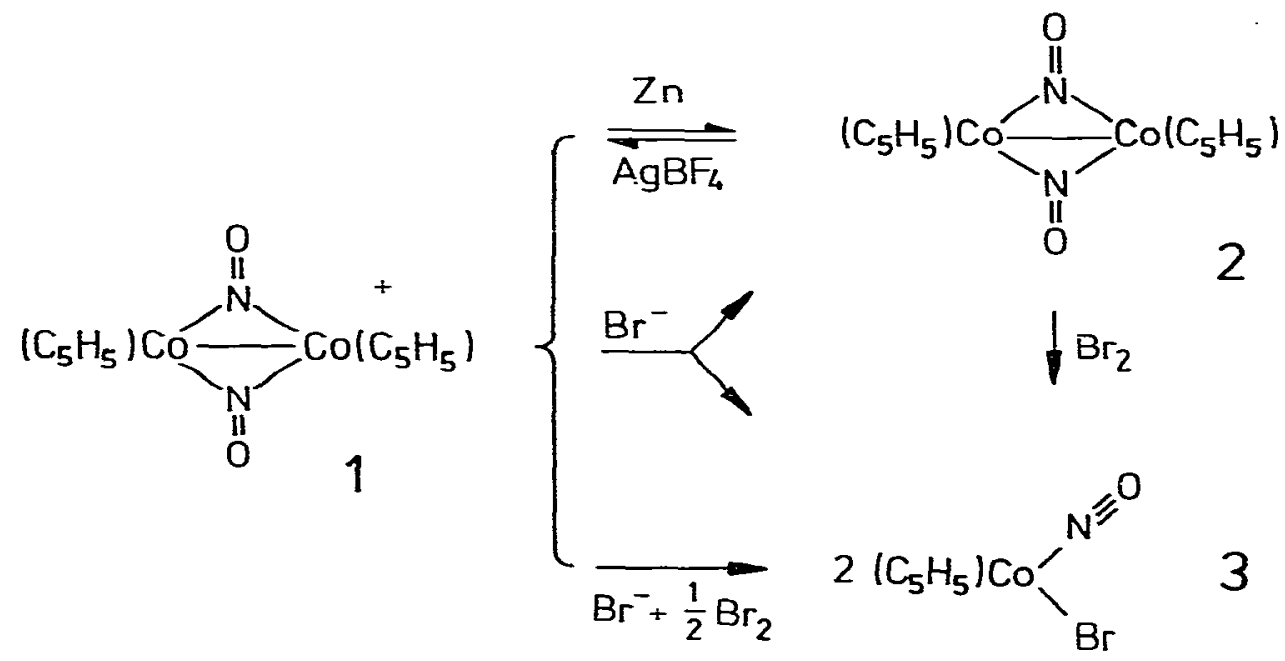

When a solution of 1 in $\mathrm{CH}_{2} \mathrm{Cl}_{2}$ is stirred with an excess of solid $\mathrm{KBr}$, its IR spectrum after about $8 \mathrm{~h}$ indicates conversion to a mixture of $\left(\mathrm{C}_{5} \mathrm{H}_{5}\right) \mathrm{Co}(\mathrm{NO}) \mathrm{Br}$ 
( $\nu(\mathrm{NO})$ at $\left.1830 \mathrm{~cm}^{-1}\right)$ [7] and $\left(\mathrm{C}_{5} \mathrm{H}_{5}\right)_{2} \mathrm{Co}_{2}(\mu-\mathrm{NO})_{2}$, i.e. a disproportionation of the mixed-valence oxidation state of $\mathrm{Co}$ in compound 1 . If carried out with equimolar amounts of tetrabutylammonium bromide in $\mathrm{CH}_{2} \mathrm{Cl}_{2}$ solution, this disproportionation reaction is instantaneous, even at temperatures around $0^{\circ} \mathrm{C}$. Since the neutral nitrosyl dimer 2 is converted in the bromo derivative 3 by treatment with $\mathrm{Br}_{2}$, a practically quantitative conversion of the cation 1 in the nitrosyl bromo derivative 3 occurs when $\mathrm{CH}_{2} \mathrm{Cl}_{2}$ solutions of 1 are treated at $0^{\circ} \mathrm{C}$ with a mixture of 1 equivalent of tetraethylammonium bromide and $1 / 2$ equivalent of bromine. This synthesis of compound 3 demonstrates that a controlled oxidation of the air-stable cation 1 represents a convenient route to mononuclear $\left(\mathrm{C}_{5} \mathrm{H}_{5}\right) \mathrm{Co}(\mathrm{NO})$ derivatives.

\section{Experimental}

Solvents were thoroughly dried and freed from dissolved oxygen. All manipulations were performed under an atmosphere of nitrogen in Schlenk type glassware. $\mathrm{C}_{5} \mathrm{H}_{5} \mathrm{Co}(\mathrm{CO})_{2}$ was prepared according to ref. 8. $\mathrm{NOPF}_{6}, \mathrm{NOBF}_{4}$ and $\mathrm{AgBF}_{4}$ were purchased from Fluka $\mathrm{AG}$ and used without further purification.

Preparation of $\left(\mathrm{C}_{5} \mathrm{H}_{5}\right)_{2} \mathrm{Co}_{2}\left(\mu-\mathrm{NO}_{2} \mathrm{PF}_{6}\right.$

To a slurry of $212 \mathrm{mg} \mathrm{NOPF} 6(1.2 \mathrm{mmol})$ in $10 \mathrm{ml} \mathrm{CH}_{2} \mathrm{Cl}_{2}$ is added at room temperature a solution of $218 \mathrm{mg} \mathrm{C}_{5} \mathrm{H}_{5} \mathrm{Co}(\mathrm{CO})_{2}(1.2 \mathrm{mmol})$ in $5 \mathrm{ml} \mathrm{CH}_{2} \mathrm{Cl}_{2}$. The mixture is then heated to $38^{\circ} \mathrm{C}$ until the IR bands at 2130 and 1900 $\mathrm{cm}^{-1}$ have disappeared $(1.5-2 \mathrm{~h})$. After removal of solvent in vacuo, the residue is washed with three $5 \mathrm{ml}$ portions of toluene and then dissolved in a small volume of $\mathrm{CH}_{2} \mathrm{Cl}_{2}$; the solution is filtered, covered with a layer of pentane and kept at $-50^{\circ} \mathrm{C} .\left(\mathrm{C}_{5} \mathrm{H}_{5}\right)_{2} \mathrm{Co}_{2}(\mu-\mathrm{NO})_{2} \mathrm{PF}_{6}$ separates as dark red platelets.

Yield: $122 \mathrm{mg}$ ( $45 \%$ of theory). The product was recrystallized from $\mathrm{CH}_{2} \mathrm{Cl}_{2}$ /pentane.

Elemental analysis: Found: $\mathrm{C}, 26.76 ; \mathrm{H}, 2.18 ; \mathrm{N}, 6.06 . \mathrm{C}_{10} \mathrm{H}_{10} \mathrm{O}_{2} \mathrm{~N}_{2} \mathrm{Co}_{2} \mathrm{PF}_{6}$ calcd.: $\mathrm{C}, 26.49 ; \mathrm{H}, 2.22 ; \mathrm{N}, 6.18 \%$.

An analogous procedure using $\mathrm{NOBF}_{4}$ instead of $\mathrm{NOPF}_{6}$ leads to $\left(\mathrm{C}_{5} \mathrm{H}_{5}\right)_{2} \mathrm{Co}_{2}$ $(\mu-\mathrm{NO})_{2} \mathrm{BF}_{4}$.

Synthesis of $\left(\mathrm{C}_{5} \mathrm{H}_{5}\right) \mathrm{Co}(\mathrm{NO}) \mathrm{Br}$ (3) from $\left(\mathrm{C}_{5} \mathrm{H}_{5}\right)_{2} \mathrm{Co}_{2}(\mu-\mathrm{NO})_{2}(2)$

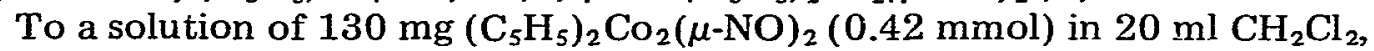
cooled to $-78^{\circ} \mathrm{C}$, a $\mathrm{CH}_{2} \mathrm{Cl}_{2}$ solution of $67.2 \mathrm{mg}(0.42 \mathrm{mmol})$ of $\mathrm{Br}_{2}$ is added during $1 \mathrm{~h}$. The product, obtained from the dark green solution after removal of solvent at room temperature, is recrystallized twice from $\mathrm{CH}_{2} \mathrm{Cl}_{2} /$ pentane. Its IR spectrum shows a strong $\nu$ (NO) absorption at $1830 \mathrm{~cm}^{-1}$.

Elemental analysis: Found: $\mathrm{C}, 26.34 ; \mathrm{H}, 2.10 ; \mathrm{N}, 5.56 . \mathrm{C}_{5} \mathrm{H}_{5} \mathrm{NOCoBr}$ calcd.: C, 25.67; H, 2.15; N, 5.99\%.

Conversion of 1 to $\left(\mathrm{C}_{5} \mathrm{H}_{5}\right) \mathrm{Co}(\mathrm{NO}) \mathrm{Br}$ (3)

To a solution of $158 \mathrm{mg}(0.4 \mathrm{mmol})$ of $\left(\mathrm{C}_{5} \mathrm{H}_{5}\right)_{2} \mathrm{Co}_{2}(\mu-\mathrm{NO})_{2} \mathrm{PF}_{6}$ in $25 \mathrm{ml}$ $\mathrm{CH}_{2} \mathrm{Cl}_{2}$, cooled to $0^{\circ} \mathrm{C}$, is added during $2 \mathrm{~h}$ solution of $84 \mathrm{mg}(0.4 \mathrm{mmol})$ of tetraethylammonium bromide and $32 \mathrm{mg}(0.2 \mathrm{mmol})$ of $\mathrm{Br}_{2}$ in $10 \mathrm{ml} \mathrm{CH} \mathrm{CH}_{2}$. The green product solution is warmed to room temperature and evaporated to 
dryness. The residue is extracted with $40 \mathrm{ml}$ of toluene, and the extract is covered with a layer of pentane and cooled to $-40^{\circ} \mathrm{C}$, whereupon $\left(\mathrm{C}_{5} \mathrm{H}_{5}\right) \mathrm{Co}$ (NO)Br separates as a dark powder.

Yield: $151 \mathrm{mg}$ (81\% of theory).

\section{Acknowledgements}

This work was financially supported by Deutsche Forschungsgemeinschaft, by Fonds der Chemischen Industrie and by research funds of the University of Konstanz. We thank Professor Huttner for access to the diffractometer and Mr. Laszlo Zsoinai for helpful advice on the structural work.

\section{References}

1 S. Clamp, N.G. Connelly and J.D. Payne, J. Chem. Soc., Chem. Comm., (1981) 897.

2 I. Bernal, J.D. Korp. G.M. Reisner and W.A. Herrmann. J. Organometal. Chem.. 139 (1977) 321.

3 H. Brunner, J. Organometal. Chem., 12 (1968) 517.

4 G.M. Sheldrick, Univ. Göttingen, 1981.

5 N.E. Schore, C.S. Ilenda and R.G. Bergman, J. Amer. Chem. Suc., 98 (1976) 256.

6 R.E. Ginsburg. L.M. Cirjak and L.F. Dahl, J. Chem. Soc., Chem. Comm., (1979) 468.

7 H. Brunner and S. Loshot, Z. Naturforsch. B, 28 (1973) 314: S. Loshot, Thesis Universität Regensburg. 1972.

8 T.S. Piper. F.A. Cotton and G. Wilkinson. J. Inorg. Nucl. Chem., 1 (1955) 165. 